\title{
Underlying Dimensions of Ecocentric and Anthropocentric Environmental Beliefs
}

\author{
María Amérigo ${ }^{1}$, Juan Ignacio Aragonés ${ }^{2}$, Belinda de Frutos ${ }^{3}$, \\ Verónica Sevillano ${ }^{2}$, and Beatriz Cortés ${ }^{1}$ \\ ${ }^{1}$ Universidad de Castilla-La Mancha \\ ${ }^{2}$ Universidad Complutense \\ ${ }^{3}$ Universidad San Pablo CEU
}

\begin{abstract}
This study focuses on the cognitive components of general environmental attitudes. Taking as a starting point the scale of Thompson and Barton (1994) to identify ecocentric and anthropocentric motives in environmental conservation, the beliefs that guide attitudes in the person-environment relationship are analyzed. Confirmatory factor analysis was used to contrast the tripartite structure of these beliefs - based on egoistic, socioaltruistic, and biospheric aspects - with a two-dimensional structure that confronts ecocentric and anthropocentric orientations. The results obtained from two samples, a student sample $(n=212)$ and a sample from the general population of Madrid $(n$ $=205$ ), indicate the existence of a three-dimensional structure of environmental beliefs: an anthropocentric dimension based on the instrumental value of the environment for human beings, a biospheric dimension that values the environment for its own sake, and, lastly, an egobiocentric dimension that values the human being within nature as a whole.
\end{abstract}

Keywords: environmental beliefs, anthropocentrism, ecocentrism, self in nature

\begin{abstract}
La presente investigación está centrada en los componentes cognitivos de las actitudes generales hacia el medio ambiente. Partiendo de la escala utilizada por Thompson y Barton (1994) para identificar motivos ecocéntricos y antropocéntricos en la conservación medioambiental, se analizan las creencias que orientan la relación individuo-medio ambiente. Mediante análisis factorial confirmatorio se contrasta una estructura tripartita de estas creencias basada en dimensiones egoístas, socioaltruistas y biosféricas con una estructura bidimensional en la que se enfrentan una orientación ecocéntrica y una orientación antropocéntrica. Los resultados obtenidos con dos muestras, una de estudiantes $(n=212)$ y otra extraída de la población general de la ciudad de Madrid $(n=205$ ), apuntan hacia la existencia de una estructura de tres dimensiones de las creencias ambientales: una dimensión antropocéntrica vinculada al valor instrumental del medio ambiente para el ser humano; una dimensión biosférica que contempla el medio ambiente por el valor intrínseco de éste y, finalmente, una dimensión egobiocéntrica que valora al ser humano en la naturaleza.

Palabras clave: creencias hacia el medio ambiente, antropocentrismo, ecocentrismo, self en la naturaleza
\end{abstract}

This work was funded as part of a research project financed by the Ministerio de Ciencia y Tecnología. Dirección General de Investigación (BSO2002-03459).

Correspondence concerning this article should be addressed to María Amérigo, Facultad de Humanidades, Universidad de CastillaLa Mancha, Plaza de Padilla, 4, 45071 Toledo (Spain). E-mail: Maria.Amerigo@uclm.es

Translation: Virginia Navascués Howard 
In the analysis of the relationship of human beings and their natural environment, one of the approaches that has produced the most empirical progress from a psychosocial perspective corresponds to the investigations carried out by the group of Paul C. Stern (Stern \& Dietz, 1994; Stern, Dietz, \& Guagnano, 1995; Stern, Dietz, \& Kalof, 1993). This approach is similar to the expectancy value of attitudes and beliefs, which contemplates the cognitive elements of attitudes. Thus, this approach analyzes environmental concern from the framework of beliefs about the consequences that environmental deterioration could have for oneself, for others, or for the biosphere- the nonhuman elements of the planet. Beliefs about the consequences of environmental deterioration are motivated or dynamized by valuesunderstood as stable structures that are generated in the socialization process and that guide action (Stern \& Dietz, 1994) — so that these values are a framework from which to selectively interpret information about the environment.

In various works (Stern \& Dietz, 1994; Stern, Dietz, \& Kalof, 1993; Schultz \& Zelezny, 1998) and starting with the universal structure of human values developed by Shwartz (Schwartz, 1994; Schwartz \& Bilsky, 1990), a relation has been empirically established between "egoistic," "socioaltruistic," and "biospheric" value orientations and beliefs about the consequences of environmental deterioration for oneself, for human beings in general, and for nonhuman elements of the planet, respectively. Thus, people who emphasize the consequences of environmental deterioration for oneself (one's own health, lifestyle, etc.) seem to base these beliefs on egoistic values; those who underline the consequences of environmental deterioration for human beings in general base their beliefs on socioaltruistic values; and lastly, those who underscore the consequences of environmental deterioration for animals, plants, and ecosystems base their beliefs on biospheric values.

The work of Stern, Dietz, and Guagnano, (1995) has led to the incorporation of all this research within a theoretical framework, establishing relations among values, general beliefs about the environment or world views, beliefs and attitudes about specific environment conditions, and behaviors concerning the environment, which has guided subsequent research (Johnson, Bowker, \& Cordell, 2004; Poortinga, Steg, \& Vlek, 2004).

Schultz (2000, 2001) empirically verified the existence of a tripartite structure-egoistic, socioaltruistic, and biospheric — of beliefs about environmental deterioration from the cross-cultural content analysis of the following question: "What is the environmental problem that concerns you the most concern and why" (Schultz, 2000, p. 395). The results were used to elaborate instruments to measure beliefs about the consequences of environmental deterioration for oneself, for others, and for animals and plants. The tripartite structure was obtained and confirmed by means of factor analysis and confirmatory factor analysis applied to various samples.
Other authors look upon general beliefs about environmental concerns as having two dimensions that confront an anthropocentric with an ecocentric viewpoint in the person-environment relation. From the former perspective, the above-mentioned egoistic and socioaltruistic dimensions would merge into a single dimension in which the human being would be the center of the relation. In contrast to this anthropocentric view, there is an alternative in which the individual and the environment would be on equal terms, forming a unit that could be referred to as an ecocentric perception of the relation.

Authors such as Thompson and Barton (1994), when analyzing the motives or values that underlie environmental concerns, identified a profile of anthropocentric individuals who value the natural environment because of its contribution to the quality of human life, and a profile of ecocentric individuals who value nature itself. Similar to this conceptualization are the instrumental and spiritual viewpoints, respectively, proposed by Stokols (1990), or the structure found by Hernández, Suárez, Martínez-Torvisco, and Hess (2000), in which the three dimensionsanthropocentrism, progress, and naturalism-represent an expanding view of person-environment relations as opposed to a naturalist view.

More recently, an analysis of the dimensionality of a series of six scales reported in the literature and developed to measure environmental attitudes showed the relevance of a negatively related two-dimensional model: a dimension of use related to the dominance of nature and alteration of natural resources by human beings and a dimension related to the "enjoyment of nature and conservation of natural resources" (Milfont \& Duckitt, 2004, p. 293).

These proposals coincide with those derived from the approach of the "New Ecological Paradigm" versus the "Dominant Social Paradigm" or the "Paradigm of Human Exceptionalism" (Dunlap \& Van Liere, 1978; Dunlap, Van Liere, Merting, \& Jones, 2000; Milbrath, 1986). This approach analyzes the transition towards a new social system that, as a consequence of the environmental deterioration caused by human beings, involves a necessary change in beliefs, attitudes, values, and lifestyles.

Thompson and Barton (1994) elaborated a scale to measure the motives that lead people to environmental conservation, including aspects linked to anthropocentric dimensions (12 items), ecocentrism (12 items), and environmental apathy (9 items). However, a detailed examination of this scale reveals that the 12 items of the ecocentric dimension refer to two different aspects: On the one hand, there are items about physical or psychological benefits for the individual, brought about by the mere fact of being in or thinking about nature. For example, item 28, "Being out in nature is a great stress reducer for me" (p. 152). These items are related to the positive emotional effects produced by contact with nature. The protagonist is the self and it is the only direct beneficiary of the goodness of the 
natural environment. Hence, these items could be considered to be related to an egoistic dimension, the self in Nature, which could be called "egobiocentric." On the other hand, the remaining ecocentric items refer to biospheric aspects that emphasize the intrinsic value of Nature. For example, item 26: "Nature is valuable for its own sake" (Thompson $\&$ Barton, p. 152). Thus, when examining the instrument designed by these authors to measure ecocentrism, it can be seen that this dimension is oriented to two different viewpoints: (a) a psychosocial perspective that contemplates the human-being-in-nature and in which the environment is valued as an element that procures the individual's physical and psychological well- being, and (b) a strictly biospheric dimension in which the environment is valued intrinsically and that contemplates the nonhuman elements of nature, in the sense of the works of Schultz $(2000,2001)$ and Stern et al. (Stern \& Dietz, 1994; Stern et al., 1993). Thus, two different dimensions within the ecocentric dimension established by Thompson and Barton could be hypothesized: an egobiocentric dimension and a biospheric dimension.

In contrast, with regard to the anthropocentric dimension of Thompson and Barton's (1994) scale, the 12 items refer to aspects about the possible benefits of environmental protection for human beings in general and for future generations. This anthropocentric dimension is related to the socioaltruistic dimension noted in the above-mentioned works of the groups led by Schultz and Stern.

In a recent work, Amérigo, Aragonés, Sevillano, and Cortés (2005), using exploratory methodology, contrasted a reduced version of Thompson and Barton's (1994) scale with the scale of beliefs about the consequences of environmental deterioration used by Schultz (2001). They found that in the latter scale, the egoistic and socioaltruistic dimensions merged into a single dimension, and that the ecocentrism and anthropocentrism dimensions measured by Thompson and Barton also appeared.

In this sense, the purpose of this investigation is to study in more detail the structure of general beliefs about the environment in an attempt to cast some light on the conceptual aspects. Specifically, the aim is to test the twodimensional ecocentric and anthropocentric model of environmental beliefs, contrasting it with a three-dimensional model in which the ecocentric dimension defined by Thompson and Barton (1994) splits into two dimensions, a biospheric and an egobiocentric dimension. Therefore, in addition to working with confirmatory methodology, we will contrast the two models in samples of different characteristics.

Once the structure of environmental beliefs is confirmed, we will analyze their predictive validity, following the hypothesis posited in the work of Thompson and Barton (1994), according to which individuals whose cognitive structure is closer to the ecocentric pole will display a higher tendency to engage in behaviors that involve personal commitment with the environment, in comparison to anthropocentric subjects. The detailed study of the cognitive structure involved in human beings' interpretation of their environment and, specifically, of environmental concerns, will no doubt lead to a better understanding of the relations between environmental attitudes and ecological behavior.

\section{Method}

\section{Participants}

In order to perform this investigation, two samples with quite different characteristics were employed. First, we used a sample comprising 212 university students from the cities of Talavera de la Reina (34\%), Toledo (21.2\%), and Madrid $(44.8 \%)$, ages between 18 and 24 years $(M=2.2, S D=$ 1.57 ) and a sex distribution of $20.8 \%$ men and $79.2 \%$ women.

To guarantee the representativeness of the data obtained in this sample of students, the study was replicated with individuals from the general population. This second sample was made up of 205 participants from the city of Madrid, ages between 19 and 65 years $(M=38.95, S D=$ 12.40) and a sex distribution of $52.7 \%$ men and $47.3 \%$ women.

\section{Procedure and Measures}

The student sample filled in a self-administered questionnaire in the classroom during their normal academic schedule. The sample from Madrid was recruited by two collaborators who delivered the questionnaire to the participants if they were within the established age (33\% of the participants in each of the intervals of 18-30, $30-45$, and 45-65 years, respectively) and sex (50\% men and $50 \%$ women) quotas. Mean time employed to fill in the questionnaire was 10 minutes in both samples. The data of this study were collected between February and March of 2003.

To measure beliefs about the environment, we used a reduced version of the scale of Thompson and Barton (1994), which was adapted to the Spanish context. We selected 15 items from the original 24 items to measure each of the three hypothesized dimensions: egobiocentric (5 items), biospheric ( 5 items), and anthropocentric ( 5 items), as displayed in Table 1. The items were written in the form of 5-point Likert scale. We chose these items on the basis of the results of a previous empirical study in which Thompson and Barton's original scale was refined, using the data obtained in various samples of subjects who filled in the scale (Aragonés, Amérigo, \& Cortés, 2000; González \& Amérigo, 1999). 
Table 1

Items Selected from the Scale of Thompson \& Barton (1994, p.152) with the Proposed Dimensions of Egobiocentrism, Biospherism, and Anthropocentrism

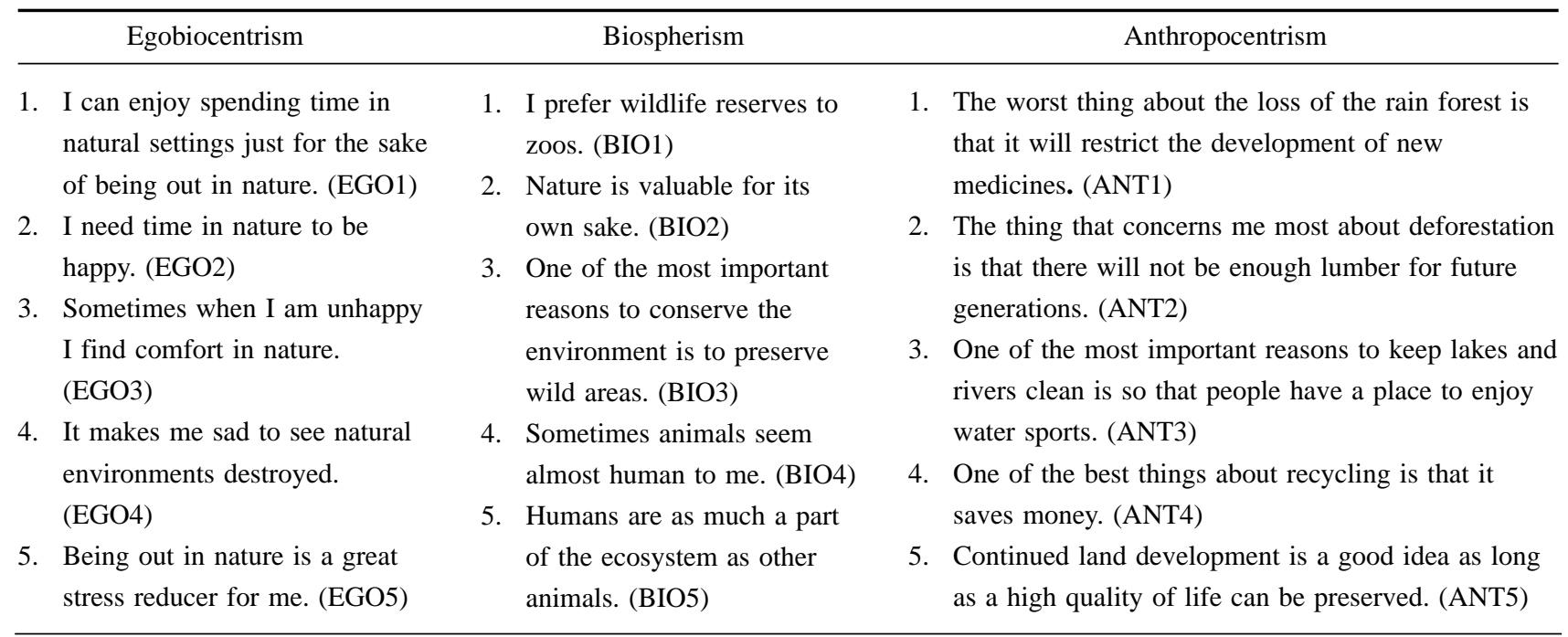

Participants were subsequently requested to respond to a series of sociodemographic questions, such as age and sex. Lastly, following the example of Thompson and Barton (1994), they were asked to leave a telephone number so they could participate in a future environment protection campaign that the University was designing. This item, which was considered a dichotomic variable (the person left a phone number/did not leave a phone number), was considered a measure of the participant's intention to carry out a pro-environmental behavior.

\section{Results}

First, the two hypothesized models were compared: Model 1, made up of two factors, compared to Model 2, with a three-factor structure. Confirmatory factor analysis with the Amos program (version 4.0) was conducted using the maximum likelihood (ML) procedure. The model was estimated with two separate matrixes, one for each sample, according to the recommendations of Arbuckle (1999). With this procedure, the parameters of each sample can be estimated, and a better fit to the data can be achieved. Thus, the existence of significant differences in the estimation of the parameters of the two samples can be verified. The two models were tested by data analysis, the first model corresponding to the original one of Thompson and Barton (1994), with its two dimensions of ecocentrism and anthropocentrism. The second model proposed the three dimensions of anthropocentrism, biospherism, and egobiocentrism.

Fit of the model. The comparison of the chi-square statistic of the two models showed that the three-factor model fit the empirical data better than the two-factor model and the difference was statistically significant, $\chi^{2}(178, N=$ $417)=426.937$ and $\chi^{2}(174, N=417)=346.732$, for the two-factor and the three-factor model, respectively.

Taking as reference point the measures of fit, although the two-factor model achieved a close fit to the empirical data, and the three-factor model attained satisfactory fit values. The root mean square error of approximation (RMSEA) describes the differences between the specified and the empirical model, adjusting the size of the sample. Values equal to or less than .05 indicate a good fit (Browne \& Cuddeck, 1993). The two-factor model obtained a value that is reasonably close $($ RMSEA $=.068)$, but the three-factor model obtained a RMSEA value of .049 , which indicates a good fit. The goodness-of-fit index (GFI) for acceptable models should be higher than .90 (Jöreskog \& Sörbom, 1984). The GFI value for the twofactor model achieved a close fit $(\mathrm{GFI}=.869)$, whereas the three-factor model obtained a satisfactory value (GFI $=.901)$.

Parameter estimation. As shown in Table 2, all the estimated parameters of the factor structure were statistically significant in both samples. The estimated factor loadings were between .19 and .79. Most of the weights were over .40. Regarding the differences between the two samples, only two indicators (bio1 and bio2) obtained statistically significant differences, with the weight being higher in the sample from the general population. Therefore, it can be assumed that there were no important differences between the two samples in the factor structure of the scale, and it can be stated that the students have the same structure of environmental beliefs as the general population. 
Table 2

Standard Parameter Estimation for Model 1 and Model 2

\begin{tabular}{|c|c|c|c|c|c|}
\hline & Latent Variable & Indicators & $\begin{array}{l}\text { Standard parameters } \\
\text { student sample }\end{array}$ & $\begin{array}{c}\text { Standard parameters } \\
\text { general population sample }\end{array}$ & \\
\hline \multirow[t]{16}{*}{ Model 1} & Anthropocentrism & ANT1 & .541 & .465 & \\
\hline & & ANT2 & .768 & .618 & \\
\hline & & ANT3 & .607 & .646 & \\
\hline & & ANT4 & .556 & .424 & \\
\hline & & ANT5 & .530 & .441 & \\
\hline & Ecocentrism & $\mathrm{BIO} 1$ & .208 & .446 & \\
\hline & & $\mathrm{BIO} 2$ & .404 & .576 & \\
\hline & & $\mathrm{BIO} 3$ & .187 & .332 & \\
\hline & & $\mathrm{BIO} 4$ & .192 & .307 & \\
\hline & & $\mathrm{BIO5}$ & .510 & .247 & \\
\hline & & EGO1 & .439 & .508 & \\
\hline & & EGO2 & .752 & .656 & \\
\hline & & EGO3 & .704 & .556 & \\
\hline & & EGO4 & .426 & .434 & \\
\hline & & EGO5 & .647 & .704 & \\
\hline & Latent Variable & Indicators & $\begin{array}{l}\text { Standard parameters } \\
\text { student sample }\end{array}$ & $\begin{array}{c}\text { Standard parameters } \\
\text { general population sample }\end{array}$ & Critical ratio \\
\hline \multirow[t]{15}{*}{ Model 2} & Anthropocentrism & ANT1 & .538 & .472 & .000 \\
\hline & & ANT2 & .773 & .569 & -.813 \\
\hline & & ANT3 & .609 & .712 & .981 \\
\hline & & ANT4 & .552 & .402 & -.213 \\
\hline & & ANT5 & .527 & .457 & .247 \\
\hline & Biospherism & BIO1* & .190 & .543 & $2.643^{*}$ \\
\hline & & $\mathrm{BIO} 2 *$ & .455 & .793 & $2.466^{*}$ \\
\hline & & $\mathrm{BIO} 3$ & .452 & .471 & 1.384 \\
\hline & & $\mathrm{BIO} 4$ & .487 & .209 & -.386 \\
\hline & & $\mathrm{BIO5}$ & .625 & .300 & .000 \\
\hline & Egobiocentrism & EGO1 & .429 & .520 & .000 \\
\hline & & EGO2 & .773 & .671 & -.904 \\
\hline & & EGO3 & .724 & .620 & -.930 \\
\hline & & EGO4 & .377 & .407 & .634 \\
\hline & & EGO5 & .665 & .736 & .492 \\
\hline
\end{tabular}

*Significant differences at $p<.01$.

As expected, when analyzing the relation between the factors, we found that the parameter estimation of the relation between the Egobiocentrism Factor and the Biospherism Factor was statistically significant in both samples, $\phi=.383$, $\mathrm{p}<.01$ and $\phi=.615, \mathrm{p}<.01$, for students and general population, respectively. Anthropocentrism had no statistically significant relation with egobiocentrism in either of the two samples. Lastly, the Anthropocentrism Factor had no significant relation with the Biospherism Factor in the student sample; however the correlation between these two factors was statistically significant and negative in the general population, $\phi=-.298, \mathrm{p}<.05$. 
Reliability and validity of the three-dimensional scale ${ }^{l}$. The psychometric properties of the three-dimensional scale show that the internal consistency of the three dimensions is acceptable. Cronbach's alpha was $.69(M=12, S D=3.8)$ for the anthropocentrism dimension, $.53(M=20.5, S D=$ 2.7) for the biospheric dimension, and .73 $(M=20.1, S D$ $=3.1$ ) for the egobiocentrism dimension. Although the alpha value of the biospheric scale was low, it can be considered acceptable, given the reduction of items compared to the original scale and the scarce amount of research carried out with it.

An analysis of the predictive validity of the three dimensions was carried out on the intention of performing a pro-environmental behavior by measuring the subject's commitment (i.e., leaving a phone number) to participate in a future environmental campaign. The results of the analysis of variance indicated that the three scales discriminate the intention to carry out this commitment (see Table 3). Thus, the people who had no intention of becoming involved in ecological behaviors in the future obtained higher mean scores on the Anthropocentric scale, $F(1,415)=5.046$, $p=.025$. With regard to the Biospherism and Egobiocentrism scales, the people who left a phone number with the intention of engaging in future behaviors obtained higher mean scores on both scales, and the difference in scores was statistically significant, $F(1,415)=4.619, p=$ .032 , and $F(1,415)=5.971, p=.015$, for biospherism and egobiocentrism, respectively.

\section{Discussion}

Although the results obtained in this investigation support the idea of a two-factor ecocentric/anthropocentric structure of beliefs about the relations between people and their environment - as reported by Amérigo et al. (2005) using exploratory factor analysis-they achieve a better fit when contemplating a three-dimensional structure: egobiocentric, anthropocentric, and biospheric. Thus, a more detailed analysis of the ecocentric dimension reported by Thompson and Barton (1994) indicates that, although ecocentrism is a globalizing concept, it seems to include two concepts: the self in nature (egobiocentrism) and Nature itself (biospherism). These results are confirmed both in the sample of students and in the sample from the general population. The analysis of correlations among the diverse measurements reveals that the anthropocentric dimension is independent of the egobiocentric dimension and also-although only in the student sample - of the biospheric dimension. This last dimension has a negative correlation with anthropocentrism in the general population sample.

One of the most interesting aspects of this investigation is the predictive validity of the three studied dimensions with regard to the intention to engage in ecological behavior. According to our results, the people who scored highest in the anthropocentric dimension were the least likely to engage in future ecological behaviors, whereas the people who scored highest in the biospherism and egobiocentrism dimensions were more likely to carry out ecological actions. Thompson and Barton (1994) obtained similar results in their Ecocentrism scale, but they did not find such relations in the scale of anthropocentrism with a student sample. In contrast, González and Amérigo (1999), although they found differences in the ecocentric and anthropocentric scales along the same lines as this investigation, these differences did not reach statistical significance. The small sample size of the group of persons who left their telephone number $(n=$ 12) may be the explanation for this.

In view of the results obtained, one could conceptualize people-environment relations by means of a structure with two different levels of analysis, which would assume both Thompson and Barton's (1994) bidimensional proposal and the three-dimensional proposals of Stern et al. (Stern \& Dietz, 1994; Stern et al., 1993) and Schultz (2000, 2001). Thus, at the higher level, the two dimensions that coincide with what the literature has labelled ecocentrism and anthropocentrism would be defined. At a second level, each one of these dimensions would in turn split into another two. In the case of ecocentrism, this refers to two concepts, one that would represent the biospheric aspect, and the other,

Table 3

Contrast of the "Intention to Engage in Ecological Behavior" in the three Subscales

\begin{tabular}{lcccccc}
\hline & $\begin{array}{c}\text { Levene's contrast } \\
\text { of variance equality }\end{array}$ & & $\begin{array}{c}\text { No ecological intentions } \\
n=336\end{array}$ & $\begin{array}{c}\text { Ecological intentions } \\
n=81\end{array}$ & \\
\hline Subscale & $F$ & $p$ & $M$ & 11.1 & 5 & 5.046 \\
\hline Anthropocentrism & .995 & .319 & 12.1 & 21.1 & 4.619 & .025 \\
Biospherism & 1.953 & .163 & 20.4 & 20.9 & 5.971 & .015 \\
Egobiocentrism & .016 & .899 & 19.9 &
\end{tabular}

1 As the samples showed no differences in factor structure, hereafter, the analyses will consider both samples conjointly. 
the self-in-nature, labelled egobiocentrism. This dimension could be compared to the dimension analyzed empirically by Grenstad and Wollebaek (1998) with regard to "Eckersley's ecocentric approach," in which the biospheric pole would be compared to the "autopoietic value theory," according to which all living beings capable of reproduction have an intrinsic value and deserve moral consideration. The egobiocentric pole would coincide with "transpersonal ecology and eco-feminism," in which self and nature are linked by relational and interdependent connections. In the case of anthropocentrism, the two extremes would correspond to egoism and altruism, thus emphasizing a psychosocial level of analysis in the perception of personenvironment relations. It would be interesting for future research to verify this dual level of analysis with regard to beliefs about the environment.

In this sense, future research should attempt to develop measuring procedures to verify the proposed structure, as well as to confirm the presence of these dimensions in cultures in which the person-environment relation established by individuals is different from the Western outlook. That is to say, research should determine whether these pure profiles of biospheric subjects exist in cultures with a different tradition from the Jewish-Christian tradition. This would also confirm that one of the obstacles in putting an end to the current ecological crisis lies in the deep roots of current Western society's anthropocentric beliefs. As acknowledged some time ago by White (1967, p. 1206) “...despite Copernicus, the whole cosmos spins around our small globe. Despite Darwin, in our hearts, we are not part of the natural process."

\section{References}

Amérigo, M., Aragonés, J.I., Sevillano, V., \& Cortés, B. (2005). La estructura de las creencias sobre la problemática ambiental. Psicothema, 17, 246-251.

Aragonés, J.I., Amérigo, M., \& Cortés, B. (2000, September). Las creencias, los valores y la preocupación por el medio ambiente. Unpublished communication presented at the VII National Congress of Social Psychology. Oviedo, Spain.

Arbuckle, J.L. (1999). Amos 4.0 user's guide. Chicago: Small Waters Corporation.

Browne, M.W., \& Cuddeck, R. (1993). Alternative ways of assessing model fit. In K.A. Bollen \& Long (Eds.), Testing structural equation models (pp. 136-162). London: Sage.

Dunlap, R.E., \& Van Liere, K. (1978). The new environmental paradigm. Journal of Environmental Education, 9, 10-19.

Dunlap, R.E., Van Liere, K.D., Merting, A.G., \& Jones, R.E. (2000). Measuring endorsement of the new ecological paradigm: A revised NEP scale. Journal of Social Issues, 5, 425-442.

González, A., \& Amérigo, M. (1999). Actitudes hacia el medio ambiente y conducta ecológica responsable. Psicothema, 11, 13-25.
Grendstad, G., \& Wollebaek, D. (1998). Greener still? An empirical examination of Eckersley's ecocentric approach. Environment and Behavior, 3, 653-675.

Hernández, B., Suárez, E., Martínez-Torvisco, J., \& Hess, S. (2000). The study of environmental beliefs by facet analysis. Research in the Canary Islands, Spain. Environment and Behavior, 32, 612-636.

Johnson, C.Y., Bowker, J.M., \& Cordell, H.K. (2004). Ethnic variation in environmental belief and behavior: An examination of the New Ecological Paradigm in a social psychological context. Environment and Behavior, 36, 157-186.

Jöreskog K.J., \& Sörbom, D. (1984). LISREL VI user's guide. Mooresville, IN: Scientific Software.

Milbrath, L.W. (1986) Environmental beliefs and values. In M.G. Hermann (Ed.), Political psychology (pp. 97-138). San Francisco: Jossey-Bass.

Milfont, T.L., \& Duckitt, J. (2004). The structure of environmental attitudes: A first-and second-order confirmatory factor analysis. Journal of Environmental Psychology, 24, 289-303.

Poortinga, W., Steg, L., \& Vlek, Ch. (2004). Values, environmental concern, and environmental behaviour. A study into household energy use. Environment and Behavior, 36, 70-93.

Schultz, P.W. (2000). Empathizing with nature: The effects of perspective-taking on concern for environmental issues. Journal of Social Issues, 56, 391-406.

Schultz, P.W. (2001). The structure of environmental concern: Concern for self, other people, and the biosphere. Journal of Environmental Psychology, 21, 327-339.

Schultz P.W., \& Zelezny, L. (1998). Values and proenvironmental behavior. A five-country survey. Journal of Cross-Cultural Psychology, 29, 540-558.

Schwartz, S.H. (1994). Are there universal aspects in the structure and contents of human values? Journal of Social Issues, 5, 19-45.

Schwartz, S.H. \& Bilsky, W. (1990). Toward a theory of the universal content and structure of values: Extensions and crosscultural replications. Journal of Personality and Social Psychology, 58, 878-891.

Stern, P.C., \& Dietz, T. (1994). The value basis of environmental concern. Journal of Social Issues, 5, 65-84.

Stern, P.C., Dietz, T., \& Guagnano, G.A. (1995). The New Ecological Paradigm in social-psychological context. Environment and Behavior, 27, 723-743.

Stern, P.C., Dietz, T., \& Kalof, L. (1993). Value orientations, gender, and environmental concern. Environment and Behavior, 25, 322-348.

Stokols, D. (1990). Instrumental and spiritual views of peopleenvironment relations. American Psychologist, 45, 641-646.

Thompson, S.C.G., \& Barton, M. (1994). Ecocentric and anthropocentric attitudes toward the environment. Journal of Environmental Psychology, 14, 149-157.

White, L. (1967). The historical roots of our ecologic crisis. Science, 155, 1203-1207.

Received November 11, 2005

Revision received March, 2, 2006 Accepted June 30, 2006 